\title{
Research Article on Hurdles faced during implementation of Project Controls in Indian Construction Industry
}

\author{
Sagar Gaur \\ (Prince2 Registered Practitioner, Certified Project Manager (IPMA Level-C)), \\ B. Tech (Civil), JUIT (HP) \& PG in Project Engineering \& Management (PEM), NICMAR \\ (Pune), MBA (Project Management) - Pursuing from Westford University College, \\ Sharjah, UAE (Awarding body UCAM, Spain), and working in Ramboll India Pvt. Ltd. \\ DOI: 10.29322/IJSRP.11.12.2021.p12031 \\ http://dx.doi.org/10.29322/IJSRP.11.12.2021.p12031
}

\begin{abstract}
Project controls in construction project is very much essential for a successful planning and project completion. Implementation of project controls in Indian construction industry is very much vital as Indian construction industry is lacking in implementation of project management process/tools and facing several issues/ delays. Implementation of project controls also need proper organization, and the front-end responsible persons need to be more focused in managing project controls department. This study provides an empirical review on the hurdles faced by the Indian construction industry while the implementation of project controls. In this study, a survey method is used for understanding the practical experiences faced by Indian construction industry in the implementation of project controls. 434 participants were involved in the survey and several questions related to the project control in Indian construction industry were asked. The responses conclude that Indian construction industry is struggling in managing/implementing project controls, hence, facing several hurdles which are delaying the projects in terms of time and cost. Three main issues determined in this study which are mostly faced by the Indian construction industry which are lack of experience in project controls, lack of proper training, and lack of concern of the on-site supervisors. Indian construction industry must be more organized, and the management needs to be more concerned for a planned, dedicated, and appropriate project controls department.
\end{abstract}

Index Terms- Project Controls, Implementation of project control, issues in project controls, Indian construction sector

\section{INTRODUCTION}

$\mathrm{T}$ The Indian construction industry is rapidly growing and making a substantial contribution to the country's overall economy. Real estate and urban development make up, the bulk of the Indian construction industry. The Real Estate section includes residential, office, retail, hotels, and leisure parks. Sub-segments of the urban development sector include water and sanitation, public transportation, education, and healthcare. By 2020, the construction industry will account for 9 percent of India's gross domestic product (GDP) [1]. However, as this sector continues to grow and develop, some concerns and challenges have arisen, slowing the industry's progress [2]. The primary concern is the management of construction projects. Construction project management includes laborers, on-site supervisors, project planners, investors, and project managers. In most building projects, the communication link between them produces disagreement, which results in additional expense and delay [2]. This article sheds light on the potential hurdles faced by the construction industry in India for the implementation of project control. The suggestions are also mentioned, which must be implemented for a better approach and development. India's yearly expenditure budget is currently Rs. 438,795 crores, despite the country's overall "Gross National Product" (GNP) being at Rs. 2200,000 crores or more [3]. Over the years, civil engineering projects have accounted for more than half of total budget expenditure. The construction industry serves as a catalyst for economic growth in the country; investment in this sector accounted for 6.5 percent of GDP growth in 2003. Each rupee invested in the construction sector results in a rise in GDP of Rs.0.80, compared to Rs.0.20 and Rs.0.14 for agriculture and manufacturing, respectively. When compared to other industries, statistics indicate that this sector of the economy generates 4.7 times the revenue and 7.76 times the job possibilities [3]. Due to the efforts of the Indian construction industry and the Planning Commission, construction has been granted industrial status. This implies that the country's construction sector, which employs more than 3.1 million people, will place a premium on formal planning and above-board financial planning.

The majority of studies attempting to shed light on activities that enhance project results has concentrated on generic project success strategies [4]. According to experts, construction managers cannot focus exclusively on one aspect of a project's success [5]. For example, project pre-planning, change management, and information technology have been highlighted as critical practices that have a major impact on the schedule and cost performance of projects [6]. Standardized project management tools, leadership abilities, and methods have all been identified as critical factors in determining the success of a project [7]. On the other side, the three most critical success factors for projects were clearly defined goals and objectives, management support, and adequate funds/resources. Communication has been identified as a critical factor in project success [8]. Project 
stakeholders favored elements such as commitment, communication, and project personnel as essential success factors [9]. It has been stated that the project team's commitment, the client's competency, and the contractor's competence all play a role in explaining the overall results of design and build projects [10]. Similarly, the most significant of all elements with the greatest positive impact on project cost performance was discovered as collaboration among project participants. Project completion time was one of up to six performance criteria affected by a contractor's track record for completing jobs in a timely manner [11]. Project outcomes are better when the teams are smaller, focused, and less dispersed, according to studies [12]. The following section of this article will evaluate and discuss many pieces of literature regarding the use of project control and the obstacles that arise while adopting project control.

\section{LITERATURE REVIEW}

\section{Project control and its importance in the Indian Construction industry}

Project Controls are procedures for collecting and analyzing data about a project in order to keep costs and schedules on track in the Construction Industry [13] mainly done by Project Controls Department. Initiating, planning, monitoring, and managing projects, as well as communicating and closing out project expenses and schedules, are all functions of project controls [14]. In a nutshell, project controls are iterative procedures for detecting the project's status, predicting expected outcomes based on estimations, and boosting the project's performance if the projected results are unacceptable. Numerous functionalities are provided in project controls, including the following:

- Aligning initiatives to the goals and objectives of the portfolio/organization

- Creating a work-flow diagram (WBS)

- Initial project timelines were developed in collaboration.

- Putting together a risk-mitigation strategy

- Budgeting and forecasting for projects are two important aspects to consider.

- Cost control on the job

- Reporting and giving feedback

- Project strategies are being optimized to get better future results.

While a project may involve a range of variables such as quality, scope, and so on, the purpose of project controls is to emphasize the cost and schedule components, while constantly checking for risk [14]. In the hierarchy, project controls are nested beneath project controls. A project controller may report to a project manager on a single project or a portfolio of projects. Project controls are essential for effective Project control because they alert project stakeholders to possible problems and enable them to correct course if necessary. On the other hand, project controls activities must be carried out throughout the project's life cycle - from start to finish - to monitor and govern the various factors that affect cost and schedule [15]. When linked with the rest of the project control process, project controls provide timely insights that enable project stakeholders to make the best decisions at the right time.
The use of project control in the Construction industry is very much preferable as the Indian construction industry is lacking effective management [16]. The construction industry is associated with a big number of laborers and the ground level operators of the construction industry must collaborate with all levels of management and investors to create transparency within the construction project. According to a survey in $2018,90 \%$ of the participants agreed with the effectiveness of project control in construction projects [17]. Additionally, the poll reveals a correlation between project controls and success: respondents who ranked controls as "critical" were twice as likely to accomplish all project objectives. Controls were more than three times more likely to fail in projects where participants believed they were "not important at all."

These findings emphasize the critical nature of controls, all the more so in light of the frequency with which major deviations from initial project estimates have happened in the past. Project managers are aware that unexpected delays, additional costs, or problems will always occur, regardless of the size of the project, whether it is a large-scale construction project or the launch of a new website for a small business. Costs and delays can balloon into major expenses and have a ripple effect throughout the Organisation if project controls are not in place to anticipate and manage them.

\section{Processes associated with Project Controls}

The data-driven approach and meticulous attention to detail are the strengths of project controls [18]. If there's a cost overrun, the project manager wants to know why it's happening, how much money it's costing and what can be done to fix the problem if it occurs. There are several benefits to using a fully integrated project controls solution, such as reducing costs and increasing efficiency.

Let's have a look at how project controls are defined.

\section{Designing a Project/ Project Planning Documents}

Collaboration between controllers and project managers is essential when it comes to planning. Whether it's creating project plans, timeframes, work breakdown structures, or cost forecasts, planning provides everyone with a starting point from which to work during the course of the project [18].

\section{Budgeting}

The budgeting process must be integrated into project activities to properly assess costs and understand when and why deviations arise. By phasing budgets and refining data, senior management and team members can use a transparent model as a benchmark throughout the project and understand important cash flows [19].

\section{Controlling Risks}

With project controls, risk management becomes easier. In order to minimize the influence on the project's budget and schedule, it is possible to identify risks in advance, monitor them periodically (by updating the risk register), and put in place procedures to deal with or reduce problems. As a bonus, it helps to guard against potential threats in the future [20]. 


\section{Controlling Change}

When a project goes over budget, it's usually because of the combined influence of several factors that aren't considered in the initial planning stages. That's why the importance of effective change management cannot be overstated. With a well-defined procedure for assessment, approval, and accountability, projects can stay on course by employing a "Change Log" tool to keep track of changes and assess their impact.

\section{Forecasting}

In order to have a better understanding of the present sources of cost and schedule overruns, project managers and controllers can improve the accuracy of estimations at the end of the project (EAC). [21] Accurate progress measurement is critical in the forecasting process. By employing a combination of popular forecasting methodologies and algorithms, project managers can extend a prediction using CTC (Cost to Complete) as and when necessary. With regular and timely reports, the project controller can respond faster and take corrective action if the project goes off course.

\section{Administration of Results}

Defining and using KPIs (Key Performance Indicators) is essential to track and forecast project health and trends [22]. Projects that use performance data, such as Earned Value Management calculations, have a success rate of 68 percent, compared to just 7 percent for those that don't, according to a recent study.

\section{Managing the Project}

This technique comprises putting in place procedures and systems to help team members communicate and collaborate. The purpose is to maintain track of status updates, capture meeting minutes and lessons learned, and manage workflows in a fluid manner so that teams may focus on actual execution rather than on boring operations. Use of RACI Chart plays a critical part in the communication/authorization process for making decisions in the project.

\section{Hurdles faced during implementation of Project Controls in Indian Construction Industry}

Although the discipline of controls is becoming more widely accepted, firms must keep in mind the following:

a) How successfully is it implemented inside the organization?

b) Is it generating the expected results?

c) Is the data reliable?

As a result of project failures, many companies blame their project controls. As a result, it's time to examine whether or not the control mechanisms have been applied correctly [23].

Take a look at some of the issues and roadblocks that project teams experience when it comes to correctly establish controls:

a) The Indian construction industry is plagued by a lack of commitment and support from upper management [24]. While monitoring is passive, control refers to actively making decisions based on analysis and reporting. As a result, without appropriate leadership authority, this is impossible to accomplish. Without autonomy and assistance, controllers cannot achieve their goals [24]. There are many construction project control teams that are understaffed or lack the financial means to invest in the necessary equipment or execute their project in a disorganized manner.

b) As a cost function, perception: Controls might be viewed as an overhead expense because they are not brought to light unless something goes wrong. This is not the actual case, however. An IPA Global study found that project controls functions cost between 0.5 percent and 3 percent of the project budget, whereas optimal practices can save anywhere from 6 percent to 20 percent [25]. Project teams and executives can be trained on the possible ROI from controls, which can help organizations overcome this perception issue.

c) Management mainly focuses on project delivery (giving more powers to site execution team) and regard functions like project controls and audit with suspicion. Thus, Site Execution Team takes advantage of the same and try to manipulate site progress reports in their favor leads to projecting wrong status to Sr. Management which in turns lead to incorrect decision making by upper management affecting project negatively in terms of cost and time. This can be handled by forging alliances rather than taking a me-versus-you strategy. Integrating the role with other aspects of Project controls is also critical for firms to be successful [26]. A project controller is not someone who stops by every few weeks or months with terrible news. Rather than that, the job should be seamlessly interwoven throughout the project's lifecycle.

d) Manual and out-of-date processes: Even when management is on board and teams are aware of the significance of project controls department, the real implementation may not keep up with the project's severe problems in the Indian construction industry [27]. Many firms continue to rely on manual processes and timeconsuming spreadsheets to track and manage risk matrices and change requests. Manual systems are more likely to remain fragmented and generate disparate data than they are to produce comprehensive insights. Additionally, they lack the requisite big-picture perspective. In the below table, a set of project control tools and the possible issues for their implementation in the construction industry is provided.

Table 1: Hurdles related with several project control tools

\begin{tabular}{|l|l|l|}
\hline $\begin{array}{l}\text { Project } \\
\text { Control } \\
\text { Tool }\end{array}$ & Function & Possible reason of failure \\
\hline EVM & $\begin{array}{l}\text { EV is a } \\
\text { quantitative } \\
\text { technique for } \\
\text { project } \\
\text { management and } \\
\text { projecting } \\
\text { predictive } \\
\text { performance. }\end{array}$ & $\begin{array}{l}\text { This tool is only useful if an } \\
\text { "Earned Value } \\
\text { Management" (EVM) } \\
\text { system is in place, so } \\
\text { projects that use it are more } \\
\text { likely to fail since they lack } \\
\text { the following elements: }\end{array}$ \\
\hline
\end{tabular}




\begin{tabular}{|c|c|c|}
\hline & & $\begin{array}{l}\text { WBS not used or approved; } \\
\text { WBS incomplete; Plan not } \\
\text { interconnected (WBS- } \\
\text { Schedule Budget); Schedule } \\
\text { and/or budget wrong; } \\
\text { Managing change not } \\
\text { utilized effectively; Cost } \\
\text { collection process } \\
\begin{array}{l}\text { inappropriate; Inaccurate } \\
\text { development; } \\
\text { managerial affect and/or } \\
\text { control }\end{array}\end{array}$ \\
\hline BIM & $\begin{array}{l}\text { Prior to } \\
\text { construction, a } \\
\text { digital technology } \\
\text { is utilized to build } \\
\text { virtually in saving } \\
\text { the time, money, } \\
\text { and waste. }\end{array}$ & $\begin{array}{l}\text { Doesn't resolve construction } \\
\text { communication difficulties, } \\
\text { and not everyone knows } \\
\text { how to use the system model } \\
\text { to deliver projects } \\
\text { successfully [28]. }\end{array}$ \\
\hline LBMS & $\begin{array}{lr}\text { Useful tool for } \\
\text { tracking personnel } \\
\text { and resource } & \text { flow } \\
\text { on production } \\
\text { tasks in task } \\
\text { management and } \\
\text { planning, } \\
\text { especially when } \\
\text { using lean } \\
\text { principles } \\
\text { eliminate waste. }\end{array}$ & $\begin{array}{l}\text { Does not cover serious } \\
\text { delays, such as terrible } \\
\text { weather. To be effective, a } \\
\text { database of resource } \\
\text { management and their } \\
\text { performance is also required } \\
\text { [28]. }\end{array}$ \\
\hline
\end{tabular}

The following section of this study will cover the methods employed to conduct this article's research and the collection of various types of data. Additionally, the authors present an analysis of the data gathered from a variety of sources.

\section{Methodology}

Quantitative research is used in this study and both the primary and secondary data are collected. The primary data collection in this study is done by following a survey method. The questionnaire prepared for the survey is oriented to the current scenario of Indian construction industry and implementation of project control in the Construction industry. Additionally, this study also uses secondary data. Secondary data is the information that has previously been released in publications, newspapers, journals, magazines, and other online resources. This study uses some previous publications and journals to gain an overview on the Indian construction industry and use of project control.

\section{DATA ANALYSIS AND RESUlt INTERPRETATION}

In this article, both primary and secondary data is collected. In the survey method, a set of questions is developed and asked to the people who are directly or indirectly involved with Indian construction industry. A total of 434 participants were involved in the survey and they respond to the questions through online communication. In most of the questions, the participants highlighted that Indian construction industry in most cases using traditional way of project management which is not as effective as it needed to be. 312 participants were agreed to implement new project control system in the construction industry which will be cost effective and will also save the time. The challenges encountered during project control implementation are also affecting the construction industry's growth, as the new project control approach needs front-end operators to be more focused and active. The majority of the 256 participants blamed the casual attitude of construction site managers and their failure to build appropriate project control in the Indian construction industry. Over twenty questions were posed to the participants.

Table 1: Issues arise while implementing project control in the construction industry

\begin{tabular}{|c|c|c|c|}
\hline $\begin{array}{l}\text { SL } \\
\text { no. }\end{array}$ & Issue & $\begin{array}{l}\text { Responses } \\
\text { percentage }\end{array}$ & $\begin{array}{l}\text { Total } \\
\text { responses }\end{array}$ \\
\hline $\mathbf{1}$ & Non-structured onsite management & $12 \%$ & \multirow{7}{*}{434} \\
\hline 2 & Improper training of project control uses & $26 \%$ & \\
\hline 3 & Casual attitude of the on-site operators to the use of project control & $17 \%$ & \\
\hline 4 & Weak regulation and control of management & $14 \%$ & \\
\hline 5 & Lack of experience regarding project controls & $21 \%$ & \\
\hline 6 & Conflict among project managers & $6 \%$ & \\
\hline 7 & Non-prioritizing risk management & $4 \%$ & \\
\hline
\end{tabular}

The table mentioned above shows the issues that are arising for project control implementation. Seven issues have been identified, and according to the opinion of the participants, improper training and a lack of experience in project control are the two major issues the Indian construction industry is facing. The participants also mentioned that the lack of concern by the onsite supervisor for project control purposes is also an issue that leads to unsuccessful implementation. These three major issues are mostly faced by the Indian construction industry, and the participants have been asked about the effectiveness of the issues on project control implementation. The responses are provided in graphs.

A total of 434 participants have weighed in on the first concern, which is poor project control training for personnel. 


\section{Improper traininng}

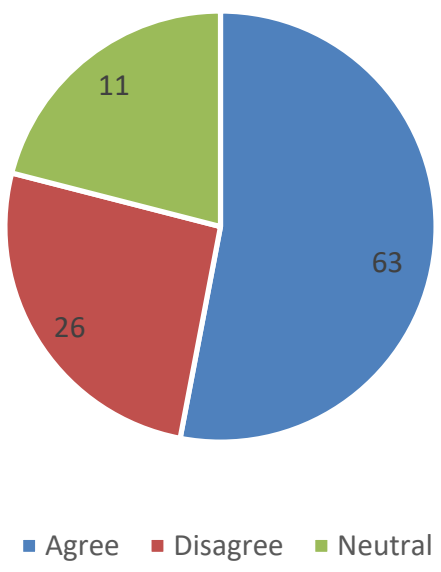

Interpretation: The issue which is mentioned above is agreed by $63 \%$ of the participants.

The second major issue arises while project control implementation is the lack of experience in its uses. The responses are presented below.

\section{Lack of experience}

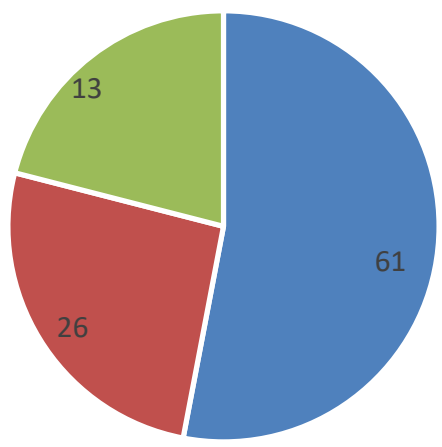

- Agree - Disagree $\square$ Neutral

Interpretation: $61 \%$ of the 434 participants agreed with this issue and $26 \%$ of participants also disagreed.

The third difficulty that arises during project control implementation is the on-site operators' lack of care for project control. 


\section{Lack of concern}

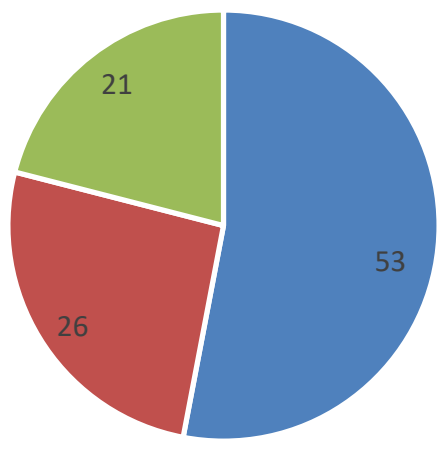

- Agree - Disagree $\quad$ Neutral

Interpretation: 53\% of the participants are agreed that lack of concern of the onsite supervisors is another issue arises while $26 \%$ of the participants disagreed.

In this study, secondary data is used and gathered from online sources. Most useful secondary resources for this study are listed below.

\begin{tabular}{|l|l|l|}
\hline Name of Journal /Website & Name of the author & Relevancy to the topic \\
\hline Invest India & A. Sriram & $\begin{array}{l}\text { This website highlights the } \\
\text { construction industry's contribution } \\
\text { to India's economy }\end{array}$ \\
\hline $\begin{array}{l}\text { International journal of project } \\
\text { management }\end{array}$ & $\begin{array}{l}\text { J. Kivilä, M. Martinsuo and L. } \\
\text { Vuorinen }\end{array}$ & $\begin{array}{l}\text { The use of project control in project } \\
\text { management id depicted in this } \\
\text { article }\end{array}$ \\
\hline $\begin{array}{l}\text { Journal of construction in developing } \\
\text { countries }\end{array}$ & $\begin{array}{l}\text { S. Loganathan, P. Srinath, M. } \\
\text { Kumaraswamy, S. Kalidindi and K. } \\
\text { Varghese }\end{array}$ & $\begin{array}{l}\text { This article provides a overview of } \\
\text { issues faced by Indian } \\
\text { construction industry recently. It also } \\
\text { shows the importance of using } \\
\text { project control to mitigate the issues }\end{array}$ \\
\hline $\begin{array}{l}\text { Journal of strategic innovation and } \\
\text { sustainability }\end{array}$ & $\begin{array}{l}\text { H. Baban, Y. Nielsen and K. } \\
\text { Seneviratne }\end{array}$ & $\begin{array}{l}\text { This article emphasizes the } \\
\text { challenges and factors responsible for } \\
\text { project controls in the construction } \\
\text { industry }\end{array}$ \\
\hline Ecosys.net & Hexagon & $\begin{array}{l}\text { This website provides the issues and } \\
\text { advantages while implementing } \\
\text { project control. }\end{array}$ \\
\hline Emirat. J. Eng. Res & $\begin{array}{l}\text { S. Bhuinyan, P. Gadekar, N. } \\
\text { Agrawal, S. Basak and Y. Raut }\end{array}$ & $\begin{array}{l}\text { This article provides an overview of } \\
\text { the factors responsible for successful } \\
\text { implementation of project control }\end{array}$ \\
\hline
\end{tabular}

In this study, the survey provides the result that the construction industry is lacking proper project controls and while implementing project controls in the construction industry, a bunch of issues are arising that are placing limitations on the management processes. Many factors are identified which are the potential hurdles faced during the implementation of project controls in the Indian construction industry, which are nonstructured on-site management, improper training of project control uses, casual attitude of the on-site operators towards the use of project controls, weak regulation and control of management, lack of experience regarding project controls, conflict among project managers, and non-prioritizing risk management. According to the survey, three major issues are identified, which are mostly mentioned by the participants: lack of proper training, lack of experience, and lack of concern from the on-site supervisors. Nearly 278 people $(64 \%)$ of the responses out of 434 responses indicate the three hurdles that can be faced during project control implementation. 


\section{DISCUSSION}

The Indian construction industry is suffering from several major issues in project management, which have a direct effect on the quality and efficiency of the project. The construction industry's traditional approach to project management results in numerous errors and delays. Additionally, construction site delays result in budget increases. According to the Project Management Institute (PMI), all "international development" (ID) initiatives have time and budget overruns. According to reports [29], over $40 \%$ of Indian building projects suffered time overruns of 1 to 252 months. As a result, scholars all around the world stress the importance of good project management procedures. Experts define project management in a variety of ways. Project management is the art and science of bringing ideas to life. From idea to commissioning, the scope of Indian construction project management can be characterized as project planning, regulating, and coordination. The practice of controlling the attainment of project objectives is known as 'project management.' All of these definitions have one thing in common: achieving targeted project outcomes through systematic project management efforts.

Project control is also an important aspect of project management. Project control is a project management role that involves using skills, tools, techniques, and knowledge to establish a project baseline, followed by performance assessment to provide timely and accurate project information to the project team. On the other hand, consumers in many government projects in India exercise more project control during the implementation stage than during the development stage. However, the implementation of project control is also not easy as it requires special attention from the management team and project control experts.

Another problem with the project is that the policies and procedures aren't well defined, and the documentation is not uniform. Lack of integration of expense and schedule throughout project control was highlighted by most survey participants as a major stumbling block to properly controlling project cost and time objectives.

According to one construction executive, project control in the'real sense' does not exist in India since it requires the integration of time and costs, which is not often the case. Due to a lack of management buy-in and a lack of a project control culture throughout the business, project control is frequently performed half-heartedly and with insufficient investment and training. As a result, management must foster a culture of project control among all employees and provide all required assistance and encouragement. This issue is entirely due to the lack of adequate project control training and knowledge among project team members. Construction and project management employees would be more effective at project control, according to practitioners, if they recognized the concept of project control more than they do now. This is because many of them believe project control is all about Gantt charts and are unfamiliar with terms like "earned value analysis," "progress analysis," and "Scurves." If a business is truly committed to completing projects on time and within budget, it must not only build the necessary project control structures and procedures, but also provide the necessary training to ensure that they are applied appropriately.
Effective project team training including contractor training, is critical to the smooth functioning and utilization of project control techniques. A significant degree of project control is delegated to the contractor, who is only responsible for creating and maintaining schedules as well as generating weekly and monthly status reports. Quality control is currently delegated to third-party experts in India. This is used in public initiatives as a technique of increasing system transparency. While the quality assurance plan (QAP) clearly states testing, frequency of testing, and interpretation of outcomes, the effective execution, monitoring, and controls are all areas that need to be improved.

\section{6. CONCLUSION AND SUGGESTIONS}

The Indian construction industry is expanding, and proper project control implementation could help it achieve new heights of success and higher standards. There is some awareness and comprehension of project control, its methodologies, and benefits ("Transparency," "Higher productivity," and "Efficiency" as the industry modernizes), and how project control can be effective to keep the high standard. The Indian construction sector is emerging, with a fair balance of turnover and interaction across diverse professions, thanks to the growing economy and demand, international investor interest in India, and ongoing major advancements in India, with more to come. Project control's features ("Transparency", "Adaptability", and "Modernization") should improve the industry's image and be recognized by all parties involved, including contractors, clients, vendors, stakeholders, and end-users. There is an increasing awareness of the shortcomings of current processes and techniques, as well as an understanding of the industry's future difficulties and milestones. The current generation of experts is attempting to put project control into reality. However, due to the conventional and labor-intensive structure of the sector, implementation of project control faces challenges. Encouragement and support from construction organizations, such as project control training for existing employees and new hires, are required for the successful implementation of Project control. Growing demands and the industry's standing should not detract from the importance of the quality triangle, which should not be excessively impacted by project cost and profit considerations. While the various phases of a project receive a lot of attention, the overall process has to be updated and relevant improvements implemented.

Finally, the public and private sectors of the Indian construction industry handle project control in markedly different ways. Excessive bureaucracy, poor project execution, concessions in quality and standards, self-interest, insufficient transparency, and corruption all contribute to this. This suggests a need to adjust government policies and the method in which public-sector activities are implemented. To keep up with expanding market demand, the Indian construction industry's productivity and efficiency must be increased. Simultaneously, the industry must institute project management in order to maintain a competitive edge in the market. With India's growing economy, foreign investment, and the possibility of significant infrastructure development, the industry's current approach to project management must be modified in order to adapt to changing trends 
and markets, meet future challenges, and compete successfully with foreign construction industries.

\section{REFERENCES}

[1] [1] A. Sriram, "Invest India," National investment promotion and facilitation agency, july 2021. [Online]. Available: https://www.investindia.gov.in/sector/construction. [Accessed 17 October 2021].

[2] [2] S. Loganathan, P. Srinath, M. Kumaraswamy, S. Kalidindi and K. Varghese, "Identifying and addressing critical issues in the Indian construction industry: Perspectives of large building construction clients," Journal of Construction in Developing Countries, vol. 22, no. 1, pp. 121-144, 2017.

[3] [3] A. L. a. C. V. R. Murty, "Challenges before Construction Industry in India," Indian Institute of Technology, Kanpur, 2007.

[4] [4] J. S. G. L. S. a. B. T. Larsen, "Factors affecting schedule delay, cost overrun, and quality," Journal of Management in Engineering, vol. 32, no. 1, p. 04015032, 2016.

[5] [5] S. C. A. a. Y. C. Leu, "A GA-based fuzzy optimal model for construction time-cost trade-of," International Journal of Project Management, vol. 19, pp. 47-58, 2001.

[6] [6] L. a. S. W. O. Ritchie, "Carrying out qualitative analysis," in Qualitative research practice: A guide for social science students and researchers, London, Eds, J. Ritchie, J. Lewis, SAGE publications, 2003, pp. 219-262.

[7] [7] D. a. F. J. White, "Current practice in project management - An empirical study," International Journal of Project Management, vol. 20, no. 1, pp. 1-11, 2002.

[8] [8] E. D. S. P. J. a. N. O. Besteiro, "Success factors in project management," Business Management Dynamics, vol. 4, no. 9, pp. 19-34, 2015.

[9] [9] Y. a. M. N. Yong, "Critical success factors for Malaysian construction projects: an empirical assessment," Construction Management and Economics, vol. 31, no. 9, pp. 959-978, 2013.

[10] [10] K. a. J. K. Iyer, "Factors Affecting Cost Performance Evidence from Indian Construction Projects," International Journal of Project Management, vol. 23, pp. 283-295, 2005.

[11] [11] F. Ling, "How project managers can better control the performance of design-build projects," International Journal of Project Management, vol. 23, no. 3, pp. 477-488, 2004.

[12] [12] O. P. T. M. A. C. d. M. H. R. d. O. Sanchez, "Cost and time project management success factors for information systems development project," IJPM, vol. 35, pp. 1608-1626, 2017.

[13] [13] J. Kivilä, M. Martinsuo and L. Vuorinen, "Sustainable project management through project control in infrastructure projects," International Journal of Project Management, vol. 35, no. 6, pp. 1167-1183, 2017.

[14] [14] H. Baban, Y. Nielsen and K. Seneviratne, " Exploring the Potentials of Smart and Sustainable Project Controls Within the Construction Industry: Drivers and Challenges," Journal of Strategic Innovation and Sustainability, vol. 15, no. 3, pp. 55-69, 2020.

[15] [15] P. Pishdad-Bozorgi, X. Gao, C. Eastman and A. Self, " Planning and developing facility management-enabled building information model (FMenabled BIM)," Automation in Construction, vol. 87, pp. 22-38, 2018.

[16] [16] S. Dixit, . A. Pandey, S. Mandal and S. Bansal, "A study of enabling factors affecting construction productivity: Indian scnerio," Int. J. Civ. Eng. Technol, vol. 8, no. 6, pp. 741-758, 2017.

[17] [17] J. Zuo, X. Zhao, Q. Nguyen, T. Ma and S. Gao, "Soft skills of construction project management professionals and project success factors: A structural equation model," Engineering, Construction and Architectural Management, vol. 25, no. 3, 2018.

[18] [18] S. Malik, F. Fatima, A. Imran, . L. Chuah, J. Klemeš, I. Khaliq, S. Asif, M. Aslam, F. Jamil, A. Durrani and . M. Akbar, "Improved project control for sustainable development of construction sector to reduce environment risks," Journal of Cleaner Production, vol. 240, p. 118214, 2019.

[19] [19] V. Vaishnavi, S. M and P. Dutta, "A study on the influence of factors associated with organizational readiness for change in healthcare organizations using TISM," Benchmarking: An International Journal, vol. 26, no. 4, 2019.

[20] [20] N. Siraj and A. Fayek, "Risk identification and common risks in construction: Literature review and content analysis," Journal of Construction Engineering and Management, vol. 145, no. 9, p. 03119004, 2019.

[21] [21] H. Leon, H. Osman, M. Georgy and M. Elsaid, "System dynamics approach for forecasting performance of construction projects," Journal of Management in Engineering, vol. 34, no. 1, p. 04017049, 2018.

[22] [22] H. B. D. S. and R. G. , "Evaluation of Key Performance Indicators of Integrated Project Delivery and BIM Model for Infrastructure Transportation Project in Ahmedabad, India through Decision-Making Approach," Journal of The Institution of Engineers (India): Series A, vol. Series A, pp. 1-17, 2021.

[23] [23] O. Abbasi, E. Noorzai, G. Jafari and M. Golabchi, "Exploring the causes of delays in construction industry using a cause-and-effect diagram: case study," Journal of Architectural Engineering, vol. 26, no. 3, p. 05020008 , 2020.

[24] [24] M. Singh, S. Deep and R. Banerjee, "Risk management in construction projects as per Indian scenario," International Journal of Civil Engineering and Technology, vol. 8, no. 3, pp. 127-136, 2017.

[25] [25] Hexagon, "Project Controls: Key Elements, Benefits and Challenges," Ecosys, 2020. [Online]. Available: https://www.ecosys.net/knowledge/whatis-project-controls/. [Accessed 1710 2021].

[26] [26] S. Bhuinyan, P. Gadekar, N. Agrawal, S. Basak and Y. Raut, "Measuring Project Performance and Success Factors of Construction Sites," Emirat. J. Eng. Res., vol. 16, no. 1, pp. 23-32, 2019.

[27] [27] S. Singh, A. Bala, S. Dixit and D. Varshney, "Critical analysis of causes of delay in residential construction projects in India," International Journal of Civil Engineering and Technology, vol. 9, no. 1, pp. 330-345, 2018.

[28] [28] K. S. Y. N. Heveine Baban, "Exploring the Potentials of Project Controls within the Construction Industry: Drivers and Challenges," in Proceedings of the International Conference on Industrial Engineering and Operations Management, Dubai, 2020.

[29] [29] P. Sagarkumar, "Analysis for the Causes of Delay in Construction Projects," International Journal for Research in Applied Science \& Engineering Technology, vol. 8, no. 1, pp. 1-3, 2020

[30] [30] T. Bauer, "Research Philosophy and Method," Springer, pp. 69-84, 2017.

[31] [31] B. Awuzie and P. McDermott, "An abductive approach to qualitative built environment research: A viable system methodological exposé," Qualitative research journal, vol. 17, no. 4, 2017.

[32] [32] A. Moser and I. Korstjens, "Series: Practical guidance to qualitative research. Part 3: Sampling, data collection and analysis.," European journal of general practice, vol. 24, no. 1, pp. 9-18, 2018

\section{AUTHORS}

First Author - Sagar Gaur, Working in MNC in Gurgaon in the field of Project Management under Project Controls Department, having experience of more than 12 Years in Construction Industry (India and Abroad).

Address: 239, Mangal Niwas, 01 ${ }^{\text {st }}$ Floor, Khuni Pul, Begum

Bridge Road, Meerut (UP) 250001, India

Phone: +91 9971100695, Email: sagargaurmrt@gmail.com 
International Journal of Scientific and Research Publications, Volume 11, Issue 12, December 2021

This publication is licensed under Creative Commons Attribution CC BY. 